\title{
Capital Market Investors' Attitudes in Bangladesh: Evidence and Policy Implications
}

\author{
Kazi Mostafa Arif*, Md. Alamgir Hossain Bhuiya \\ Department of Economics, Islamic University, Kushtia, Bangladesh \\ Email address: \\ arif@economicsiu.ac.bd (K. M. Arif), bhuiyaalamgir@economicsiu.ac.bd (Md. A. H. Bhuiya) \\ ${ }^{*}$ Corresponding author
}

\section{To cite this article:}

Kazi Mostafa Arif, Md. Alamgir Hossain Bhuiya. Capital Market Investors' Attitudes in Bangladesh: Evidence and Policy Implications. International Journal of Economics, Finance and Management Sciences. Vol. 4, No. 6, 2016, pp. 344-348.

doi: $10.11648 /$ j.ijefm.20160406.15

Received: October 13, 2016; Accepted: October 25, 2016; Published: November 7, 2016

\begin{abstract}
The aim of the study is to examine the effect of behavioral biases on stock market investors' decision making in Dhaka Stock Exchange. We focused on three well-documented biases i.e., disposition effect, herd behaviour and gambler's fallacy. In this study we utilized primary data which were collected through our survey questionnaire. Based on these information, descriptive statistics were employed to construct different bias grades. We explored that women do not actively participate in security market as seen on interview time although women also invest in the security market, but most of the activities in the security market are carried out by men. It is also stimulating that seventy seven percent respondents are within the economic active age group, of 30-50 years which thus indicates a positive sign of the market. Moreover, the data reveals that the greater portion of our investors are bachelor graduate. In addition to that the most of the individual investors' experience are within 3 to 10 years. After building bias grade of the above mentioned behavioral biases it can be settled that our participants are, on average, moderately affected by behavioral biases. And lastly, a hypothesis was inspected that the behavioral biases are more obvious for less experienced investors but our results support this hypothesis weakly. As we conceive that investors do not learn from experience and perform illogically in the stock market.
\end{abstract}

Keywords: Behavioral Biases, Disposition Effect, Herd Behaviour, Gambler's Fallacy

\section{Introduction}

Generally a variety of systematic biases and distortions influence market participants which consequently create systematic errors and produce incorrect and inferior performance contrary to assumption of rational market participants. In Bangladesh, individual investors behaviour are influenced by different biases, i.e., overconfidence, overtrading, disposition effect, over-reaction, greed, etc [9]. These are more exist during upward trend in the market. Market evidence suggests us a lion's portion of free-float shares is owned by individual investors and eventually regular trades are influenced by them. As a result biases and irrational attitudes simultaneously instigate price-volatility and market instability.

Bangladesh capital market has been evolving since 1990 with the development of political environment. Under investment and poor infrastructure are crucial features of
Bangladesh economy that hinder economic development which thus needs attention. In this regard organized and wellfunctioning capital market can play a vital role through facilitate investment in efficient and profitable ventures. We witnessed during 1990-2010 lots of magical moment in Banglaadesh stock market as reflected by the ratio of market capitalization to GDP (at current market price). In 1991 the ratio of market captalization was 0.9 percent and 2.1 percent in 2001. This ratio dramatically stood up 39.1 percent in 2010 [2]. Through these time the turnover ratio also increased from 1.6483 percent to 54.2524 percent. From these pictures one can deduce the better efficiency of Bangladesh's Dhaka stock exchange market. But this information was not level during that period and had been shown greater volatility.

We noticed bubble and bust episode in Dhaka stock 
exchange in 1996 debacle-the indices reached the highest level in its history in November 1996 and eventually crashed. The stock index of Dhaka stock exchange was recorded of 337 percent on November 1996 compared to the index of December 1995. Similar increases were happened in 2010. At the begining of 2009 the stock index in Dhaka stock exchange was at 2808. It increased 62 percent in the period between January-December 2009. Finally it reached to the peak level at 8919 on December 2010. Though the bubble and bust episode of 1996 and 2010 were not the same. But the reasons of the both debacle commonly were exuberant demand, acceleration in money and margin lending, narrow market leadership, structural weakness and inadequate financial knowledge of individual investors and speculation [11].

There are two common features in capital market accross the globe, i.e., bubble and bust. According to stock market literature we know bubble period are usually characterized by a number of features but the two are most striking these are: a) a period of liquidity expansion; and b) a persistent increase in stock price which some times leads to speculative behaviour among traders especially small and retailed traders [16]. During the market debacle it was noticed that a large number of traders were buying stocks only because past returns were very high. These traders are often called feedback traders. They beleive that if the stock returns were in high in the recent past, they are likely to be high in the future. In the short run stock prices go beyond its true values which makes market volatile. This makes capital market inefficient which can never be desire for companies and investors. The efficiency of capital market largely depend on attitude of individual investors in developing economy since its nature. That is why; in this paper the principal purpose is to examine behavioral patterns of capital market investors' in Bangladesh.

The study will be divided into five parts. Following this introductory part, second part will delineate objectives. Part three explores theoretical literature and previous notable works of behavioral finance. The methodology to be employed in the study will be presented in part four. Part five gives a presentation of results. Finally, part six gives conclusions and policy implications.

\section{Objectives}

Following the lead of Shlomit and et. al [14], in this study we analyze the effect of three well- documented behavioral biases on market investors' decision-making. Due to some logistic constraints the behavioral patterns (biases) we analyze are:

i) Disposition effect - investors' tendency to sell stocks that gained value and to hold on to stocks that lost value.

ii) Herd behavior - behavior of an investor imitating the observed actions of others or the movements of market instead of following her own beliefs and information.

iii) Gambler's fallacy - incorrect belief in negative autocorrelation of non-autocorrelated random sequences.

\section{Literature Review}

One aim of this section is to review theoretical exposition on behavioral finance. Recent literature demonstrates that economic and financial behavior and decision-making may be affected by various psychological effects. These effects are called "biases" or "fallacies" which based on feelings, emotions and intuition, rather then on rational considerations, and produce inferior financial performance. In present research, we concentrate on three well-documented effects. Yet there have no study found in stock literature that have analyzed spcifically the behavioral biases of capital market for Bangladesh. However few studies i.e., Sohani, Rashid and Nishat, Hussain and Nasrin explored that phychological factors effect stock index in Bangladesh.

\subsection{Disposition Effect}

One of the important behavioural aspects is disposition effect. The tendency of investors to hold losers too long and sell winners too soon [7]. In this effect it is observed that investors are very eager to realise gains but allof their losses. It is called an irrational behavior, because selling and holding decisions should depend on the perceived future value of a security, but not the purchase price. Bailey et al [3] demonstrates that the investor sells relatively more winners than losers, which indicates a positive value of the disposition effect proxy. It is costly for higher-income investors to sell winner too soon and hold loser to long because of the fact that they face higher marginal rates. Thus disposition effect could be related to tax incentives. Odean [12] also concludes evidence in favor of the disposition effect. His results were that on average 14.8 percent of the gains available are actually realized, while only 9.8 percent of the losses are realized. Frazzini [6] examines whether the disposition effect caused 'underreaction' to new information what will lead to return predictability and price drifts. With data of mutual fund holdings he builds a new measure of reference purchasing prices for individual stocks. The conclusion of the paper is that the disposition effect can induce 'underreaction' to new information. And this will indeed lead to return predictability and price drifts. The information content of the news and the investor's preference price relative to the current price determine the price pattern.

\subsection{Herd Behavior (Herding)}

While decision making individuals imitate others. This is generally referred to as herd behavior. Herd behaviour in financial markets is a natural phenomenon. Both economists and practitioners are interested in herding. Economists are interested in herding due to herd behaviour effects on stock prices which might affect their return and risk characteristics and as a result has consequences for asset pricing models. On the other hand, Practitioners are interested in herding since it 
might create profitable trading opportunities. Tan et al [15] shows the influence of investor herds has the power to drive prices away from their fundamental values. According to Chiang and Zheng [4], due to herding in the market investors need a larger number of securities that create a lower degree of correlation to reach the same degree of diversification.

\subsection{Gambler's Fallacy}

One of the fundamental misunderstanding of probability theory is gambler's fallacy. In the gambler's fallacy, an individual erroneously believes that the onset of a certain random event is less likely to happen following an event or a series of events. This line of thinking is incorrect because past events do not change the probability that certain events will occur in the future [1].

Now we turn to discuss on Bangladesh issues. Sohani [10] studied behaviour of individual investors of Dhaka Stock Exchange (DSE). It was found that psychological factor is the most dominating influence upon investor's decision making process. Micro economic factor and social factor also have influence on selecting investment securities. Macroeconomic factor has little influence on stock index. Sohani [10] also found that knowledge of financial analysis of stock market is not crucial to the investors. In fact most of the investors do not understand the process and exact meaning of index.

Rashid and Nishat [13] examined that in Bangladesh, the most influencing factors on investors' decisions are efficiency of the company, inflation rate, easy and quick transactions, transaction cost, access to the company and industry information, quality of information and prior knowledge of securities. In a study Hussain and Nasrin [8] explored that the eight most important principal factors influencing retain investors are company specific attributes/reputation, net asset value, accounting information, trading opportunity, publicity, ownership structure, influence of people and personal finance needs.

\section{Survey Design and Research Approach}

This part are heavily based on previous work of Shlomit and et. al [14]. The aim of this part is to show how the data are to be collected, by which method and sources and the process of analyzing the data. We will gather the data for this study in the framework of a sample survey. We conduct sample survey of market investors, not necessarily professional. We ask all the respondents to indicate their gender, age, and number of years of active experience in the capital market. The goal of the questionnaire is to detect if stock market investors are affected by different psychological biases. There are several approaches to determining the sample size. These include using a census for small populations, imitating a sample size of similar studies, using published tables, and applying formulas to calculate a sample size. For populations that are large, Cochran [5] developed the following equation to yield a representative sample for proportions.

$$
n_{0}=\frac{Z^{2} p q}{e^{2}}
$$

Which is valid where $\mathrm{n}_{0}$ is the sample size, $\mathrm{Z}^{2}$ is the abscissa of the normal curve that cuts off an area $\alpha$ at the tails (1- $\alpha$ equals the desired confidence level, e.g., $95 \%$ ), e is the desired level of precision, $\mathrm{p}$ is the estimated proportion of an attribute that is present in the population, and $q$ is $1-p$. To assess the behavioral biases of investors of capital market in Bangladesh the following information will be used: assume $\mathrm{p}=.2$ (maximum variability), we desire a $95 \%$ confidence interval and $\pm 5 \%$ precision. The resulting sample size is demonstrated below:

$$
n_{0}=\frac{Z^{2} p q}{e^{2}}=\frac{(1.96)^{2}(.2)(.8)}{(.05)^{2}}=246
$$

Thus, the number of individual investors brought under the preview of the study is 246 that constitute the sample. The investors therefore included in the sample are a purposive sample nature as because only those investors who agree to co-operate in the sample survey will have been selected.

\section{Result and Discussion}

\subsection{Basic Information of Respondents}

The table 1 below provides our sample descriptive statistics. This sample survey was conducted from July, 2013 to December, 2013. Table 1 shows that 246 (100\%) respondents were male. It reveals the fact that women do not actively participate in security market as seen on interview time although women also invest in the security market, but most of the activities in the security market are carried out by men. With respect to age distribution of respondents, the table also shows that $12(5 \%)$ of the respondents are within the age group $18-30$ years. Ninety two $(37 \%)$ are within the age group of 30-40 years, $99(40 \%)$ are within the age group of 40 - 50 years of age, $37(15 \%)$ are within the age group of $50-60$ years, $6(3 \%)$ are within the age group of 60 year and above. This implies that most of the respondents are within the economic active age group, of $30-50$ years which represents $77 \%$ of the total respondents.

Table 1. Sample Descriptive Statistics.

\begin{tabular}{lll}
\hline \multicolumn{2}{l}{ Capital Market Investors (246 respondents) } & \\
\hline Category & Number & Percent of Total \\
\hline $\begin{array}{l}\text { 1. Gender: } \\
\text { Men }\end{array}$ & 246 & $100 \%$ \\
2. Age: & & \\
$18-30$ & 12 & $5 \%$ \\
$30-40$ & 92 & $37 \%$ \\
$40-50$ & 99 & $40 \%$ \\
$50-60$ & 37 & $15 \%$ \\
$60+$ & 6 & $3 \%$ \\
3. Educational Qualification & & \\
Secondary & 25 & $10 \%$ \\
Higher Secondary & 12 & $5 \%$ \\
Bachelor & 111 & $45 \%$ \\
\hline
\end{tabular}




\begin{tabular}{lll}
\hline \multicolumn{2}{l}{ Capital Market Investors (246 respondents) } \\
\hline Category & Number & Percent of Total \\
\hline Masters & 98 & $40 \%$ \\
PhD & - & - \\
Others & - & - \\
4. Capital Market Investor for: & & \\
Less than 3 years & 6 & $3 \%$ \\
3 to 5 years & 104 & $42 \%$ \\
5 to 10 years & 111 & $45 \%$ \\
More than 10 years & 25 & $10 \%$ \\
\hline
\end{tabular}

Source: Authors' Field Survey

The result on educational qualification of the investors reveals that $25(10 \%)$ of the respondents have secondary school education, $12(5 \%)$ possess secondary education, 111 $(45 \%)$ are bachelor graduates, $98(40 \%)$ have masters degree in various fields. The result obtained is expected, the educational qualification of the respondents is very important in determining the respondents interest in the security market and management of security. Table 1 also exposes the comparative statistics of market experience. There we can see that less than 3 years experience has only $6(3 \%)$ person out of our sample 246,3 to 5 years $104(42 \%), 5$ to 10 years 111 $(45 \%)$ and 10 years above $25(10 \%)$. The most of the individual investors' experience are within 3 to 10 years.

\subsection{Descriptive Statistics of Bias Grades}

Table 2 concentrates descriptive statistics in this respect, and shows some general results. All the bias grades for both groups range from 2 (minimal possible grade) to 9-10 (maximal possible grade). In other words, in our sample, we have both participants who seem to be fully affected and completely unaffected by the respective behavioral patterns.

The mean bias grades range from 4.375 to 5.850 , and the majority of the participants have bias grades lower than 6 . We, therefore, may infer that our participants are, on average, moderately affected by behavioral biases.

Table 2. Basic Descriptive Statistics of "Bias Grades".

\begin{tabular}{llll}
\hline \multicolumn{2}{l}{ Individual Investors (246 respondents) } & & \\
\hline Statistics & $\begin{array}{l}\text { Disposition } \\
\text { Grade }\end{array}$ & $\begin{array}{l}\text { Gambler's } \\
\text { Grade }\end{array}$ & $\begin{array}{l}\text { Herd (Behavior) } \\
\text { Grade }\end{array}$ \\
\hline Mean & 5.3 & 4.375 & 5.85 \\
Median & 6 & 4 & 6 \\
Standard Deviation & 1.697 & 1.371 & 1.610 \\
Maximum & 9 & 8 & 10 \\
Minimum & 2 & 2 & 3 \\
Grade $[6,10]$, percent & 62.5 & 15 & 57.5 \\
\hline
\end{tabular}

Source: Authors' Field Survey

The table reports, by groups of participants, basic statistics of the "bias grades" calculated as follows:

$$
D G_{i}=G Q_{1 i}+G Q_{2 i} ; G G_{i}=G Q_{3 i}+G Q_{4 i} ; H G_{i}=G Q_{5 i}+G Q_{6 i}
$$

where: $G Q_{n i}$ is the grade (answer) given by participant $i$ for question (statement) $\mathrm{N}$. And $\mathrm{N}=1 \ldots . .6$.

\section{Conclusion and Policy Implications}

We examined the effect of three well-documented behavioral biases on stock market investors' decision making. Namely; a) Disposition effect b) Herd behavior c) Gambler's fallacy. In this regard we collected basic information through our survey questionnaire that reveals the fact that women do not actively participate in security market as seen on interview time although women also invest in the security market, but most of the activities in the security market are carried out by men. With respect to age distribution of respondents the most of the respondents are within the economic active age group, of $30-$ 50 years which represents $77 \%$ of the total respondents. The result on educational qualification of the investors exposes that the major part of our investors are bachelor graduate. The most of the individual investors' experience are within 3 to 10 years. After examining the three well documented behavioral biases it can be conclude that our participants are, on average, moderately affected by behavioral biases. Finally we examined the hypothesis that all the behavioral effects are more strongly pronounced for less experienced investors but our results support this hypothesis weakly. This means that investors do not learn from experience and behave irrationally.

The policy implication is that for a vibrant and consistent capital market, it is important to identify and assess the key dynamics, shaping the investment behaviour of individual investors. Identifying socio-economic background of investors, the extent of their financial knowledge and information needs should be ascertained the needs of investors can then be met though appropriate research. This is almost important for facilitating proper functioning of the capital market [9]. Furthermore, we notice that high participation of individual investors directly leads to high stock price volatility, and sub-optimal investment decision. Hence, this creates hindrance to market efficiency. Under such circumstances, more and more institutional participation, from the long-term perspective, should be encouraged, as relative to individual investors' participation, with appropriate policies. Thus, it is conceived that the factors which will be of enormous help to encourage a rational course of behaviour on the part of individual investors in our capital market are financial discipline and transparency, ensuring free flow of information, alongwith imparting financial knowledge and investment sophistication to individual investors.

\section{References}

[1] Albert Phang, Behaviral Finance: Key Concepts- Gambler's Fallacy. Retrieved from

$\mathrm{http} / / /$ www.investopedia.com/university/behavioral_finance/b ehavioral7.asp

[2] Bangladesh Economic Review, Finance Division, Ministry of Finance, Government of Bangladesh, Various Issues.

[3] Bailey et al. (2011) "Behavioral Biases and Mutual Fund Clieteles", Working paper, Cornell University. 
[4] Chiang, T. C. \& Zheng, D. (2010) "An empirical analysis of herd behavior in global stock markets", Journal of Banking and Finance, vol. 34, no. 8, pp. 1911-1921.

[5] Cochran, W. G. (1963) Sampling Techniques, $2^{\text {nd }}$ Ed., New York: John Wiley and Sons, Inc.

[6] Frazzini, Andrea (2006) "The disposition effect and underreaction to news", Journal of Finance 61: 4, 2017-46.

[7] Henderson, T. (2012) "Does prospect theory explain the disposition effect?" Journal of Behavioral Finance.

[8] Hossain, M. F., and Nasrin, S. (2012) 'Factors Affecting Selection of Equity Shares: The Case of Retail Investors in Bangladesh', European Journal of Business and Management, 4 (20), 110 - 124

[9] Hossain M. S. (2013) "Behavioral Biases of Stock Market in Bangladesh”, The Daily Financial Express, 21 June 2013, Dhaka, Bangladesh.

[10] Islam, Sohani (2012) 'Behavioral Finance in an Efficient Market', Global Journal of Management and Business Research, 12 (14), Version 1.0.
[11] Khaled K. I. (2011) Investigation Report of Probe Committee, Bangladesh.

[12] Odean, Terrance (1998) "Are investors reluctant to realize their losses?" Journal of Finance 53: 5, 1775-98.

[13] Rashid, M. and Nishat, M. A. (2009) 'Satisfaction of Retail Investors on the Structural Efficiency of the Market: Evidence from A Developing Country', Asian Academy of Management Journal, 14 (2), 41-64.

[14] Shlomit and et. al (2012), "Stock Market Investors: Who Is More Rational, and Who Relies on Intuition?" International Journal of Economics and Finance, Vol. 4, No. 5; May 2012.

[15] Tan, L. and et al (2008), "Herding behavior in Chinese stock markets: An examination of A and B shares", Pacific-Basin Finance Journal, vol. 16, no. 1, pp. 61-77.

[16] Wahab, M. A., and Faruq, M. O., 2012, "A Comprehensive Study on Capital Market Developments in Bangladesh", March 2012, Research Department, Bangladesh Bank, Head Office, Dhaka, Bangladesh. 